\title{
Analysis of Marketing Mix Strategy on Consumer Value in Small and Medium Enterprises in Palembang, South Sumatra
}

\author{
(Case Study of Palembang's Traditional Processed Food)
}

\author{
Riza Wahyudi ${ }^{1, *}$ M. Thoyib ${ }^{1}$ Firmansyah ${ }^{1}$ Darul Amri $^{1}$
}

\author{
${ }^{1}$ Accounting Department Politeknik Negeri Sriwijaya \\ *Corresponding author. Email: rizawahyudi70@gmail.com
}

\begin{abstract}
This research aims to determine the effect of market mix strategies on consumer value in Small Medium Enterprises in Palembang (case study of Palembang traditional processed food), by taking a sample of 180 middle-size business entrepreneurs with purposive non-probability sampling technique by distributing questionnaires from 3000 entrepreneurs as the population (Cooperatives and Small and Medium Enterprises Palembang). In order to know the partial and simultaneous relationship between marketing mix variables (Product, Price, Promotion and Place) and Consumer Value, regression analysis is used. The results of this study indicate that there is a positive and significant influence between the market mix strategy variable on consumer value, both partially and simultaneously.
\end{abstract}

Keywords: strategy, marketing mix, consumer value.

\section{INTRODUCTION}

There are at least four factors that entrepreneur needs to take into consideration in setting up the business; firstly, to choose what products can be sold and accepted by consumers continuously, secondly, at what price will be set on the product that will be sold whether at a high, medium or low price, thirdly, what promotional tools that will be used in introducing the product, online or offline and lastly, the target location / place where the product is sold, whether in traditional markets, malls, mini markets and so on. These four factors are usually shorten as four Ps that stands for Product, Price, Promotion and Place with the ultimate goal of increasing the company's revenue/sales. In order to achieve optimal sales along with the right costs or expenses to generate a reasonable profit, a strategy is needed. There are actually two strategies, namely the corporate strategy and the marketing strategy. Corporate strategies are generally long-term, while marketing strategies are short-term strategies that focus on sales and business competition tactics. Meanwhile, the corporate strategy is a long-term plan, which is a combination of business strategies based on its function to increase sales and competition from year to year continuously.
Problems with micro, small and medium enterprises MSMEs in Indonesia's economic conditions starting in 2019 began to decline, accompanied by the COVID-19 pandemic in March 2020. According to respondents and the records of SUMSEL.COM in July 2020, MSMEs, especially Palembang traditional food market, fell by $70 \%$, the entrepreneurs are only able to survive are only able to make a break even point strategy. In order to respond to this decline in sales, this study aims to provide a solution to recalculate customer value compared to customer satisfaction that is currently not widely known by small and medium enterprises. However, what actually happened was that entrepreneurs lacked knowledge about the concept of value has changed (based on the interview results with respondents). The concept of value change (value chain starting from design, calculation of cost of production, distribution and consumer value) has actually been carried out in calculating the internal cost of the company, by most traditional food entrepreneurs in Palembang. In essence, this study aims to prove the marketing mix strategy towards consumer value, not customer satisfaction. Actually consumer satisfaction is only a consumer's perception of the product or service 
that the customer feels. Meanwhile, consumer value is the difference between the benefits that customers receive and the costs that consumers pay.

\subsection{Literature Review}

The marketing mix is part of the marketing concept, which has a strategy to influence consumers to buy the products or services offered. Kotler and Armstrong (2014: 76) define marketing mix as "the set of tactical marketing tools that the firm blends to produce the response it wants in the target market". The definition states that marketing mix is a set of tactical marketing tools in the company combining the two to produce the desired response in the target market. According to Kotler and Keller (2012: 119), marketing mix is a set of marketing tools that companies use to continuously achieve their marketing goals in the target market. According to Kotler and Keller (2016: 47) four variables in the marketing mix activities have the following components:

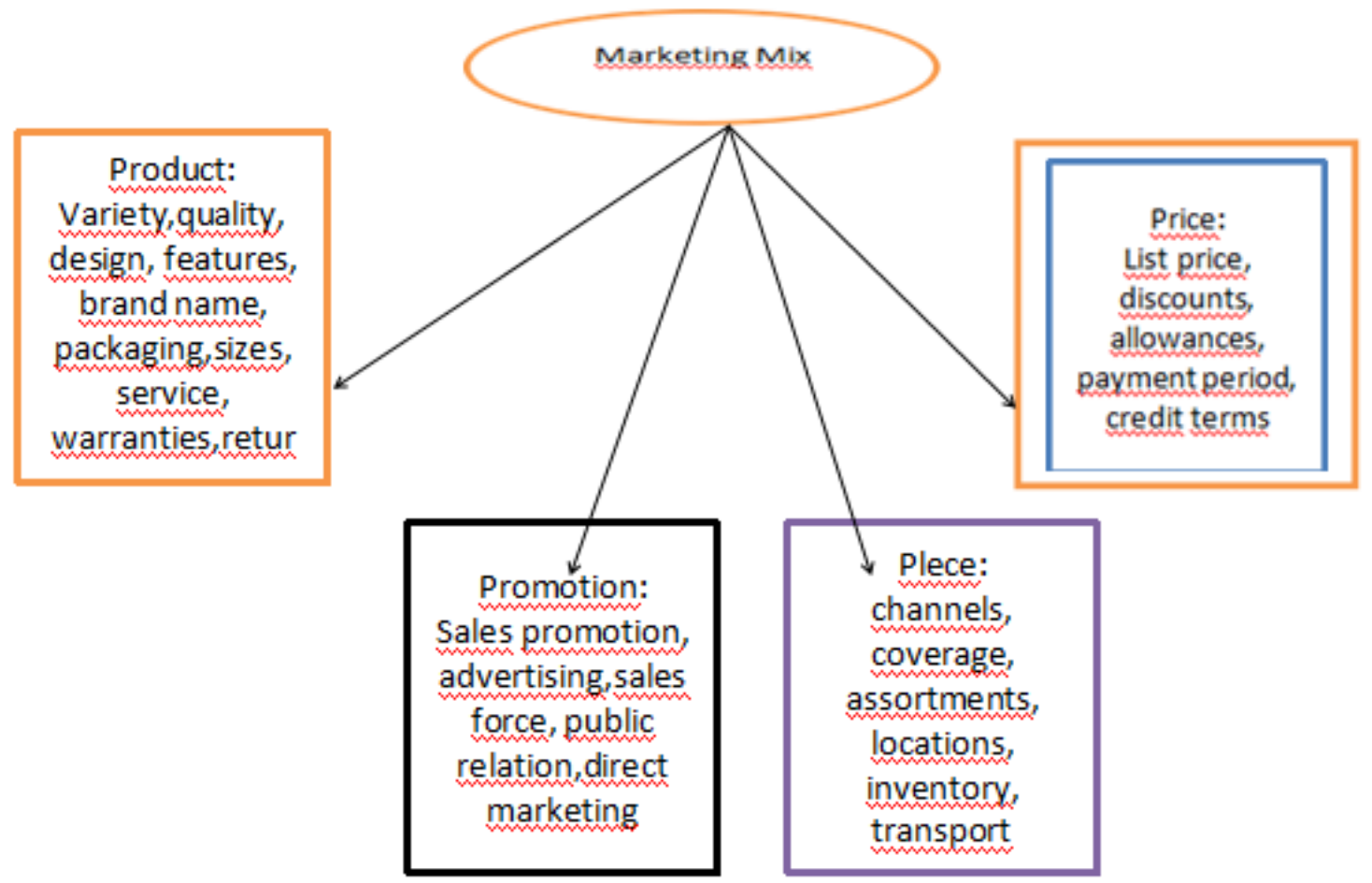

Figure 1. Marketing Mix (Kotler and Keller, 2016)

Kotler and Armstrong (2016: 27) states that "marketing is a process by which companies create value for customers and build strong relationships with customers, with the aim of capturing value from customers in return. The essence of marketing is to create customer value that is better than the value created by competitors (Kotler, 2016). Customer value relates to the use of a product and is more something that the customer feels than the seller. Customer value is the perception and what the customer feels and his evaluation of the product attributes and performance, the consequences that arise after consuming the product, which will ultimately make the customer achieve his goals in various usage situations. In this case, customer value can be categorized into 4 dimensions, namely functional value, social value, emotional value, and sacrificial value (Wang et al, 2004: 117).
In terms of customer satisfaction, Kotler and Keller (2007: 177) states that customer satisfaction is the feeling of pleasure or disappointment of a person who appears after comparing the performance of the product thought against the expected performance. According to Tjiptono (2012: 301), customer satisfaction is a situation shown by consumers when they realize that their needs and desires are as expected and are met properly.

According to Kotler and Keller (2009), the way to build customer value is to increase the benefits of the product, service, staff and image offered and reduce one or more types of costs. The strategy commonly used in building customer value is known as a generic value strategic, which is as follows: 
a. Provides more benefits at lower costs than competitors (more for less).

b. Provides more benefits at the same cost as the competitors (more for the same).

c. Provide the same benefits as competitors at lower costs (same for less).

d. Provides more benefits and greater costs than competitors (more for more).

e. Provides low benefits at lower costs than competitors (less for less).

According to Kotler and Keller (2008) as cited in Ririn and Mastuti (2016: 117), "Satisfaction is expressed as the level of feeling where a person states the results of the performance of the product/service received compared to what it is expected." Meanwhile, according to Mowen, as cited in Fandy Tjiptono (2011: 434), "Customer satisfaction is an overall attitude towards a good or service after its acquisition and use. In other words, customer satisfaction is a post-purchase evaluative assessment resulting from a specific purchase selection."

Kotler and Keller (2012: 60) states that "Customer perceived value (CPV) is the difference between the prospective customer's evaluation of all the benefits and all the costs of an offering and the perceived alternatives. " Customer value is the difference between the benefits the customer gets compared to the costs incurred. "

\section{METHODOLOGY}

This research is causality research between the independent variables of the market mix (Product X1, Price X2, Promotion X3 and Place X4) on the dependent variable (consumer value $\mathrm{Y}$ ) using multiple linear regression models $(\mathrm{Y}=\alpha+\beta 1 \mathrm{X} 1+\beta 2 \mathrm{X} 2+\beta 3 \mathrm{X} 3$ $+\beta 4 \mathrm{X} 4+€ \mathrm{i})$. The data is collected through interview and questionnaires. 200 questionnaires are distributed and only 180 are back with complete answers. Thus, the sample of this research is 180 respondents out of 500 medium-sizes entrepreneurs as the population. The questionnaire consists of 30 questions with a Likert scale, the questionnaire was tested its validity and reliability with a sample of 30 respondents, then questionnaires were distributed and the data was retested using the classical assumption test and to test the significance of the effect of the marketing mix strategy on consumer values using statistical hypothesis testing, namely the $\mathrm{t}$ test (partial test) and $\mathrm{F}$ test (Simultaneous) and it can also be seen that the determinant coefficient ( $\mathrm{R}$ Square) is calculated from the multiple regression model.

\section{RESULTS} below:

The regression results can be seen in the table

Table 1. Regression Result

\begin{tabular}{|c|c|c|c|c|c|}
\hline & \multicolumn{2}{|c|}{$\begin{array}{l}\text { Unstandardiz } \\
\text { ed } \\
\text { Coefficients }\end{array}$} & \multirow{2}{*}{$\begin{array}{l}\text { Standardiz } \\
\text { ed } \\
\text { Coefficient } \\
\text { s } \\
\text { Beta }\end{array}$} & \multirow[b]{2}{*}{$\mathrm{T}$} & \multirow[b]{2}{*}{ Sig } \\
\hline & B & $\begin{array}{l}\text { Std. } \\
\text { Error }\end{array}$ & & & \\
\hline (Constant) & $\begin{array}{l}7.04 \\
9\end{array}$ & $\begin{array}{l}1.89 \\
7\end{array}$ & & 3.717 & $\begin{array}{l}0.00 \\
0\end{array}$ \\
\hline $\begin{array}{l}\text { X1 } \\
\text { (Product) }\end{array}$ & $\begin{array}{l}0.33 \\
5 \\
\end{array}$ & $\begin{array}{l}0.03 \\
1 \\
\end{array}$ & 0.457 & $\begin{array}{l}10.69 \\
2\end{array}$ & $\begin{array}{l}0.00 \\
0 \\
\end{array}$ \\
\hline X2 (Price) & $\begin{array}{l}0.18 \\
5 \\
\end{array}$ & $\begin{array}{l}0.03 \\
9 \\
\end{array}$ & 0.192 & 4.786 & $\begin{array}{l}0.00 \\
0\end{array}$ \\
\hline $\begin{array}{l}\text { X3 } \\
\text { (Promotio } \\
\text { n) }\end{array}$ & $\begin{array}{l}0.19 \\
8\end{array}$ & $\begin{array}{l}0.02 \\
6\end{array}$ & 0.315 & 7.545 & $\begin{array}{l}0.00 \\
0\end{array}$ \\
\hline X4 (Place) & $\begin{array}{l}0.26 \\
9 \\
\end{array}$ & $\begin{array}{l}0.02 \\
8 \\
\end{array}$ & 0.387 & 9.606 & $\begin{array}{l}0.00 \\
0 \\
\end{array}$ \\
\hline
\end{tabular}

The regression model is as follows:

$$
\mathrm{Y}=7.049+0,457 \mathrm{X}_{1}+0,192 \mathrm{X}_{2}+0,314 \mathrm{X}_{3}+
$$

$0,387 \mathrm{X}_{4}+€_{\mathrm{i}}$

Based on the partial hypothesis testing (t-test), if the $t$ count is bigger than $t$ table then $\mathrm{Ha}$ is accepted and Ho is rejected and conversely when $t$ count is smaller than $\mathrm{t}$ table then $\mathrm{Ho}$ is accepted and $\mathrm{Ha}$ is rejected or when the significance value is less than $5 \%$ it can be said that the hypothesis is significance. From the table it can be seen that for product (X1), the value of t count is 10.692 which is bigger than 1.96, therefore it can be said that there is a positive and significant effect of quality product on consumer value. Furthermore, for price (X2), the t count is also bigger than 1.96 indicating that the right price has positive and significant effect on consumer value. In terms of promotion (X3), the $t$ count is also bigger than 1.96 meaning that there is a positive and significant relationship between promotion and consumer value. Lastly, the value of $t$ count for place is bigger than $t$ table showing that the right place has positive and significant effect on consumer value. Therefore, it can be concluded that, partially, there is a positive and significant effect between marketing mix and consumer value.

Table 2. Anova Result

\begin{tabular}{|l|l|l|l|l|l|}
\hline Model & $\begin{array}{l}\text { Sum of } \\
\text { Squares }\end{array}$ & Df & $\begin{array}{l}\text { Mean } \\
\text { Square }\end{array}$ & F & Sig \\
\hline Regression & 2088.072 & 4 & 522.018 & 117.288 & $\begin{array}{l}0.0 \\
00\end{array}$ \\
\hline Residual & 778.878 & 175 & 4.451 & & \\
\hline Total & 2866.950 & 179 & & & \\
\hline
\end{tabular}


Based on the table Anova, it can be said that if $\mathrm{f}$ count is bigger than $\mathrm{f}$ table then, $\mathrm{Ho}$ is rejected and $\mathrm{Ha}$ is accepted and vice versa. The table above shows that the $\mathrm{f}$ value is 117.288 which is bigger than $\mathrm{f}$ table of 3.48 meaning that $\mathrm{Ha}$ is accepted. Therefore, it can be concluded that there is a positive and significant relationship between marketing mix and consumer values, simultaneously.

Table 3. Coefficient Determination

\begin{tabular}{|l|l|l|l|l|}
\hline Model & $\mathrm{R}$ & R Square & $\begin{array}{l}\text { Adjusted R } \\
\text { Square }\end{array}$ & $\begin{array}{l}\text { Std. } \\
\text { Error of } \\
\text { the } \\
\text { Estimate }\end{array}$ \\
\hline 1 & 0.853 & 0.728 & 0.722 & 2.10968 \\
\hline
\end{tabular}

Based on the table 3 above, it can be seen that the independent variable gives contribution to dependent variable as much as $72.8 \%$ and the rest of $27.2 \%$ is affected by the factors outside the model.

\section{DISCUSSION}

Consumer value with indicators. Functional, social, emotional and sacrificial values are strongly influenced by a quality product strategy with indicators of variety of food, quality, design /motive, features/shape, brand name/trademark including the name of the shop, packaging, sizes, services, guarantees and zero percent rate of goods being return. There is $45.7 \%$ effect that shows consumer value will increase when the product is of higher quality. Consumer value with indicators. Functional, social, emotional and sacrificial values are strongly influenced by the pricing strategy in the form of discounts, allowances/ adequate supplies, payment period/providing payment terms, credit terms, with a magnitude of the effect of 19.2. \% .

Consumer value with indicators. Functional values, social values, emotional values and sacrificial values will be strongly influenced by accurate promotional strategies in the form of sale promotions, advertising, appropriate public relations and direct marketing with a large influence of $31.4 \%$. Consumer value with indicators. Functional value, social value, emotional value and sacrificial value will be strongly influenced by the place or location strategy, such as, using the right channel, large sales venues, assortments/various sales locations for exhibition venues, other crowded places, sufficient inventory if there are additional orders, smooth transportation to expand the sales place, with a large influence of $38.7 \%$.

Of the four marketing mixes, all of them have a positive and significant effect on consumer value (functional value, social value, emotional value and usefulness value) but the ones that make the biggest contribution to increase the consumer value are quality products with indicators of; variety of food, quality, design /motive, features/shape, brand name/trademark including the name of the shop, packaging, sizes, services, guarantees and zero percent rate of goods being return Meanwhile, the smallest contribution to consumer value is the marketing mix, namely price. Therefore, price is not a problem for consumers who will consume Palembang's special / traditional food.

\section{CONCLUSION}

Based on the analysis of the results and the previous discussion, some conclusions and suggestions can be drawn as follows: (1) Partially or simultaneously the four independent variables, namely quality products, the right price, the right promotion and the right place / location have a positive and significant effect on value consumers. (2) The determinant coefficient of the independent variables (Product, Price, Promotion and Location / Place) contributed to the dependent variable (consumer value) by $72.8 \%$ and the remaining $27.2 \%$ influenced by other variables outside of this research. (3) Beta coefficient is the biggest of the four coefficients of the studied variables whose influence on consumer value is the quality product variable beta, which is equal to 0.457 . Followed by Location/Place, Promotion and lastly Pricing..

\section{RECOMMENDATION}

It is recommended for the next researchers to combine marketing strategy theory (including traditional foods to promote regional tourism and increase fiscal facilities) with management accounting with the concept of value change (four chains: design, cost of goods manufactured, distribution and consumer value).

\section{REFERENCES}

[1] Best, Roger J. 2009. Market-Based Management Strategies for Growing Customer Value and Profitability. New Jersey: Pearson Education

[2] Bojanic, D. (1996). Consumer Perceptions of Price, Value and Satisfaction in the Hotel Industry: an Exploratory Study. Journal of Hospitality and Leisure Marketing 4(1), 5-22.

[3] Butz, H. \& Goodstein. (1996). Measuring Customer Value: Gaining the Strategic Advantage. New York: McGraw Hill.

[4] Expert Journal of Marketing, Volume 3, Issue 1, pp.1-10, 2015 (C) 2015 The Authors. Published by Sprint Investify. ISSN 2344-6773 Marketing.ExpertJournals.com

[5] Fornell, C. (1996). The American Customer Satiafaction Index: Nature, Purpose, and Findings. Journal of Marketing 60, 7-18. 
[6] Ghozali, Imam. 2009. Aplikasi Analisis Multivariate dengan Program SPSS. Semarang: Badan Penerbit Universitas Diponegoro.

[7] Hurriyati, Ratih. 2010. Bauran Pemasaran dan Loyalitas Konsumen. Bandung: Alfabeta

[8] James F. Engel (1994), pengertian perilaku konsumen, dalam buku Perilaku Konsumen, Edisi 6: jilid 1. Penerbit Binarupa Aksara.

[9] Kotler P, Hermawan Kartajaya, Iwan Setiawan, 2019. MARKETING, Jakarta: Penerbit: PT Gramedia Pustaka Utama, cetakan I

[10] Kotler dan Kevin lene Keller (2016). Manajemen pemasaran. Edisi 13. Indonesia: PT. Gelora Aksara pratama.

[11] Kotler, Philip dan Armstrong, Garry. 2008. Prinsipprinsip Pemasaran. Jakarta: Erlangga.

[12] Kotler dan Keller. 2009. Manajemen Pemasaran. Jakarta: Erlangga.

[13] Kotler, Philip dan Keller, 2007, Manajemen Pemasaran, Jilid I, Edisi Kedua belas, PT. Indeks, Jakarta.

[14] Mc Carthy, 2013.Manajemen Pemasaran. Jakarta:Gramedia.

[15] Rambat Lupiyoadi dan Hamdani, 2012. Manajemen Pemasaran jasa, Jakarta: Salemba Empat,

[16] Setijono, D dan Dahlgaard, J. 2007. Customer values as a key performance indicator (KPI) and a key improvement indicator (KII). Journal Measuring Business Excellence, Vol.11, No.2.
[17] Soehadi W, Agus,2016. Value Creation Approach - Strategy.Jakarta: Gramedia.

[18] Sugiyono. 2010. Metode Penelitian Kuantitatif, Kualitatif dan R\&G. Bandung: Alfabeta

[19] Sutrisna, 2012. Perilaku konsumen dan komunikasi Pemasaran, Edisi kedua. Bandung Remaja Rosda Karya.

[20] Tjiptono.F. 2012. Service Manajemen, Mewujudkan Layanan Prima. Yogyakarta: CV Andi Offset

[21] Tjiptono, Fandy. 2001. Strategi pemasaran. Edisi pertama. Andi ofset. Yogyakarta

[22] Uma Sekaran, 2006. "Metodologi Penelitian untuk Bisnis”, Edisi 4, Buku 1, Jakarta: Salemba Empat

[23] Wang, S. F. (2011). Development trends of global Internet community. Taipei, TW: The Ministry of Economy ITIS Plan.

[24] Woodruff, Robert B. 1997. Customer Value: The Next Source for Competitive Advantage. Journal of the Academy of Marketing Science, Vol.25, No.2.

[25] Yeh, C.-H., Wang, Y.-S., \& Yieh, K. (2016). Predicting Smartphone Brand Loyalty: Consumer Value and Consumer Brand Identification Perspectives. International Journal of Information Management. 36, 245-257 